\title{
FIGURAS FEMENINAS EN LA OBRA DE ALFONSA DE LA TORRE
}

\author{
María PAYERAS GRAU \\ Universidad de las Islas Baleares \\ maria.payera@uib.es
}

Resumen: Análisis transversal de la obra poética de Alfonsa de la Torre desde la perspectiva de la representación de género.

Abstract: Analysis of the cross Alfonsa de la Torre poetic work from the perspective of gender representation.

Palabras clave: Poesía. Femenina. Española. Posguerra.

Key Words: Poetry. Female. Spanish. Postwar.

Los años posteriores a la guerra civil conocieron un auge innegable de la literatura de autoría femenina. La poesía, concretamente, contó con la presencia activa de escritoras que, desde planteamientos estéticos heterogéneos, aportaron obras de indudable interés y calidad. Autoras como Carmen Con- 
de, Ángela Figuera, Esther Andreis, Pilar López, Elena Martín Vivaldi, Susana March y otras muchas pusieron voz de mujer a la expresión poética de la realidad. Del caudal de aportaciones llevadas a cabo por las poetas de esos años, hoy en fase de recuperación después de décadas de olvido, es justo referirse a la obra desarrollada por Alfonsa de la Torre, una autora segoviana recordada por pocos, pese a ser la suya una de las obras más destacadas y originales de la época. En boca de uno de sus defensores, la obra de Alfonsa de la Torre ofrece «culturalismo, exquisitez, refinamiento, lenguaje muy personal para el tiempo literario en que escribe su obra; en definitiva, otro modo muy actual de concebir la creación poética» (Guillén, 2001: 23-24).

Nacida en Cuéllar en 1918, hizo el bachiller en el Instituto de Segovia y realizó estudios de lengua y cultura italiana en Valladolid y Madrid. Se licenció en Filología Románica por la Universidad de Madrid, donde coincidió en las aulas con Carmen Conde, con Josefina Romo y con la puertorriqueña Diana Ramírez de Arellano, que, andando el tiempo, sería autora del principal estudio crítico de su obra que existe hasta la fecha. Fue alumna de Dámaso Alonso y de Joaquín de Entrambasaguas, doctorándose en 1944 con una tesis sobre Carolina Coronado. Entre 1944 y 1945 estudió lengua y literatura portuguesas en Lisboa y en Coimbra y en 1949 se trasladó a Peruggia para ampliar sus conocimientos de lengua y literatura italianas. Alfonsa de la Torre logró, de este modo, una formación académica muy superior a la que las mujeres recibían, por lo común, en aquel entonces. Durante sus años juveniles frecuentó, en compañía de otros intelectuales de la época, el famoso Café Gijón, donde conoció a García Nieto y a los otros integrantes de «Juventud Creadora». Por aquellos años, también ella había comenzado su trayectoria poética, publicando su primer libro, Égloga, en 1943. Esa primera obra, que se orientaba en la línea formalista de la época, se vería seguida en 1948 por el extenso poema titulado Oda a la reina del Irán. Hacia 1950, después de conocer a la que sería su compañera de toda la vida, se retiró casi por completo de la vida pública. Para entonces acababa de publicar la que posiblemente sea su obra principal, titulada Oratorio de San Bernardino. A la muerte de su padre, en 1952, Alfonsa se dedicó a administrar el importante patrimonio familiar, volviendo a publicar poesía sólo de forma excepcional. A este período corresponde Plazuela de las obediencias, publicada en 1969.

Su obra resulta, desde luego, muy interesante y fuera de lo común. Su erudición, a juzgar por esa misma poesía, habrá sido, sin duda, muy extensa, y de ella dan noticia también diversos ensayos de la autora sobre temas filológicos y artísticos. Detrás de sus publicaciones se intuye una personalidad rica y compleja. Su inclinación culturalista y su rigor formal ofrecen un envoltorio de clasicismo aparente a una obra que, sin embargo, aborda temas 
poco corrientes en la lírica de esos años. Por otra parte, su obra se caracteriza por problematizar la realidad de la mujer a través de representaciones femeninas muy apartadas de lo convencional.

La poesía de Alfonsa de la Torre encubre bajo una tupida capa de símbolos y una soterrada ironía la poetización de modelos femeninos abiertamente enfrentados al orden patriarcal. Este rasgo, que toma entidad, sobre todo, en sus dos últimos poemarios - Oratorio de San Bernardino y Plazuela de las obediencias - se inscribe en una obra donde la poetización de la imagen femenina, muy interesante, se lleva a cabo con rasgos de gran originalidad. Mujeres de perdición, amazonas, infanticidas, brujas y hechiceras pueblan el imaginario de Alfonsa de la Torre de un modo que no tiene equivalente en toda la poesía femenina española de esos años.

Su primer poemario, Égloga, aparece prologado por Josefina Romo, su amiga y condiscípula, que señala a Garcilaso, Fray Luis y San Juan de la Cruz entre las fuentes primordiales de la nueva poeta (Romo en Torre, 1943: 10). Este primer poemario se ciñe tanto en el metro como en los temas a las características del garcilasismo propio de la época, y adolece de un cierto tono impersonal compensado por la plasticidad de las imágenes, sobre todo aquellas que evocan el paisaje más cercano al propio horizonte afectivo de la autora.

Hacia la segunda parte del libro aparecen los poemas que mejor se acomodan al título genérico de éste. Es entonces cuando cobra fuerza una poesía de corte lírico que, en varias ocasiones, permite adivinar al trasluz la figura de la propia autora. Quizás el más revelador de los poemas sea «Viento de despedida» (Torre, 1943: 93-104), elegía por una joven mujer, evocando una íntima amistad con ella: «Con tus gracias lograste el privilegio / de compartir mis bellas soledades, / siendo de mis secretos cofre vivo» (Torre, 1943: 96). Esa compañera de la infancia, que Ramírez de Arellano se inclina a considerar imaginaria, evoca para la autora unos años irremisiblemente perdidos, en un tono intimista que también caracteriza a la segunda égloga, en la que una pastora vierte sus lamentos de amor.

La mujer se representa en esta obra en un entorno cotidiano y vinculado a la experiencia personal. Por otra parte, cuando el poema se aproxima al modo de la égloga tradicional, el poema se singulariza otorgando la palabra a la pastora, a la mujer, es decir, a aquella habitualmente reducida a objeto pasivo y mudo de los amores bucólicos, provocando, pues, una subversión del rol femenino. La mujer pasa de este modo a expresarse a sí misma, tomando conciencia de su propio ser y situación.

Oda a la reina del Irán, es un extenso poema de sentido unitario en el que se produce la confrontación de dos modelos femeninos: uno representado por 
el personaje del título y otro identificado con el sujeto lírico. La reina del Irán se presenta como un personaje legendario, habitando un tiempo y un espacio también míticos. Su imagen hierática, rodeada de lujo y sensualidad, evoca, por un lado, el enigma de la esfinge y, por otro, sugiere la idea de la pantera o la tigresa. Distante y majestuosa, vive doblemente encerrada en su jaula de oro y en su mundo interior sin que, aparentemente, nada turbe su serenidad. Su comportamiento corresponde al de una elegida. Frente a la realidad privilegiada de esta mujer, la voz poética interrumpe la evocación para emprender un sordo lamento existencial que contrapone la propia intimidad atormentada frente a la fascinación que siente por esa mítica reina.

Como contrafigura de esa legendaria «Reina del Irán», el sujeto poético se muestra en un entorno austero, sufriendo una soledad desgarradora. El «pathos» poético va cobrando intensidad a medida que el poema avanza, también por oposición al hieratismo de la reina legendaria. De algún modo el lector percibe que el contrapunto de la leyenda es necesario para velar la expresión de la intimidad por parte de un sujeto poético que se muestra pudoroso ante la efusión emocional.

Esta contraposición resulta ser en Oda a la reina del Irán un elemento estructurador del poemario, que pone en evidencia una distancia abismal entre la experiencia descrita por el sujeto poético y lo que se presenta como una construcción legendaria o mítica de la figura femenina. El procedimiento subvierte la representación patriarcal de la mujer, puesto que señala la imposibilidad de asimilar a la realidad un modelo de feminidad enigmática y distante, tan repetida en el imaginario poético masculino. Por el contrario, la confrontación entre la leyenda y la realidad potencia la imagen de una mujer que no es fría e insensible sino que está, como todo ser humano, expuesta al sufrimiento.

La obra poética de la autora alcanza su madurez en Oratorio de San Bernardino, de 1950, concebido, en su conjunto, como una obra de carácter espiritual, que describe un proceso íntimo del personaje poético, en busca de la paz interior. La portada del Oratorio de San Bernardino (Peruggia), obra destacada del Renacimiento italiano, es el pretexto temático que la autora utiliza para describir un viaje íntimo y simbólico al fondo de sí misma

Los bajorrelieves de Agostino del Duccio que cubren la fachada del monumento, así como el entorno arquitectónico y artístico de la plaza en la que se ubica, en los que se inspira la autora, aparecen reproducidos fotográficamente en el libro, lo que prueba la deuda de la palabra poética con respecto al entorno artístico y espiritual al que hace referencia.

El poemario arranca con la contemplación de un simbólico prado cuyas reminiscencias sanjuanescas llevan a pensar en una búsqueda espiritual del amor. En ese espacio de sosiego, el espíritu de la mujer se aísla de todo lo su- 
perfluo. La portada del oratorio será la superficie sobre la cual la mujer libere su pensamiento e inicie no una interpretación de la obra artística, sino una búsqueda de sí misma. El indefinible, cambiante y esquivo rostro de la paz es la meta perseguida por la peregrina. El amor centra, en primer lugar, las reflexiones de la autora - «Encuentro con el amor» (Torre, 1950: 19-22) sólo para certificar que, según su percepción, el amor es un hecho doloroso, lo que se corresponde, en la experiencia de la autora, con el reconocimiento de su propia orientación sexual, estigmatizada social y moralmente. Paso a paso, la autora va insinuando la razón del viaje poético: el conocimiento de sí misma y la aceptación de su alteridad como paso previo para su sosiego espiritual. En su viaje iniciático, la mujer - identificada por el nombre real de la autora - se representa en «Defensa de las virtudes» ante el juicio de un Dios que la ayuda a reconocerse, ante el que se siente aceptada, y que le enseña a admitir que «el amor cambia el nombre»: «Y Dios me repetía / que ese nombre era el mío, / que me llamaba Alondra, / pero yo bien sabía que me llamaba Alfonsa, / y Dios bien lo sabía» (Torre, 1950: 25). La paronomasia Alfonsa / Alondra ilustra la transformación de la mujer, su nacimiento a una nueva identidad adquirida a través del amor. El nuevo nombre, Alondra, aparte de la similitud fonética con el nombre verdadero de la autora, posee connotaciones que la asocian a la actividad poética, ya que la alondra, como otros pájaros que se distinguen por su canto melodioso, resulta una metáfora propicia del poeta. El tránsito de una a otra identidad no se realiza sin resistencia: la mujer no se reconoce en el nuevo nombre, le cuesta asimilar el cambio, lo que indica la lucha íntima que libra, y el conflicto espiritual que conlleva la aceptación de una identidad diferente a la estipulada en el orden establecido. En este poema, las virtudes, como el propio título indica, salen en defensa de la mujer, quien, redimida por esas cualidades positivas que ha desarrollado, se siente, ante los ojos de Dios, perdonada.

Alfonsa de la Torre poetiza en este tramo del libro el camino íntimo hacia la aceptación de su propia alteridad. Esa clave se desarrolla en un contexto artístico, literario y espiritual conectado con la cultura medieval y renacentista italiana, panel de fondo íntimamente ligado a la formación intelectual de la autora que le permite tamizar su confesión. Hasta aquí, el poemario describe un proceso íntimo conflictivo valerosamente afrontado por el sujeto poético. El carácter visionario de la obra, patente ya en «Defensa de las virtudes», se desarrolla e incrementa en los poemas posteriores: «Irrumpieron los ángeles», «Hasta que todo fue música» y «Campanas sobre las colinas de la Umbría». La aceptación de sí misma y la justificación ante los ojos de Dios culminan para la mujer en una suerte de éxtasis espiritual que deja en suspenso toda la realidad: «Todos los elementos dejaron la materia» (Torre, 1950: 27). Deteni- 
do el tiempo, la peregrina siente cómo todo su ser absorbe la belleza del instante: los ángeles irrumpen en su visión, la música estalla en torno a ella, la sombra de la Santísima Trinidad apacienta amorosamente su rebaño y, finalmente, todas las campanas de la Umbría suenan acordes. El único elemento discordante en el conjunto es, tal vez, el carácter tópico de los elementos que integran la visión, la disonancia perceptible entre el tema abordado - censurado por la moral católica - y la visión seráfica que sigue al reconocimiento de su alteridad, lo que sugiere una posible intención paródica en los textos.

Sin duda, la iconografía del Oratorio está engarzada al imaginario poético de la autora, que evoca escenas concretas de la portada del Duccio en su obra. Las «visiones» de la poetisa - el coro de ángeles, el estallido de la música, etc. - son, en parte, reflejo de la obra contemplada, aunque utiliza esa imaginería con fines propios. De igual modo, aunque la obra se relaciona con una temática religiosa, el discurso de la autora sólo puede considerarse religioso de forma tangencial. Formalmente, Oratorio de San Bernardino incluye poemas inspirados en la liturgia católica, como «Letanía primaveral a María en la Riviera dei Fiori», «Himnodia de las espigas» y «Antífona de Santa Cecilia». La lectura de los poemas, no obstante, descubre un tono desenfadado divergente de la intención espiritual. «Letanía primaveral a María en la Riviera dei Fiori», en consonancia con el título, es una oración invocativa a Dios Padre, a la Santísima Trinidad y a la Virgen María rogando piedad para las flores. El poema - desarrollado íntegramente en latínpor aquel entonces la única lengua litúrgica, enumera más de un centenar de especies botánicas - árboles, arbustos, flores y hongos - referidas a variedades ornamentales, medicinales, comestibles, etc., denominándolas por su nombre científico. Entre ellas, tal vez involuntariamente, se filtran varias denominaciones incongruentes con el contexto. El poema culmina con una alteración de las palabras rituales de la misa: «Agnus Dei, qui tollis carduus mundi, / parce rosis Domine / Agnus Dei, qui tollis carduus mundi, / exaudi nos Domine. / Agnus dei, qui tollis carduus mundi, / miserere floris» (Torre, 1950: 40). En conjunto, el poema tiene un sentido más bien mundano, relacionado desde el mismo título con una conocida ruta turística italiana - la Riviera dei Fiori- y su desenfado no evita un toque de humor final que a algunos podría parecer irrespetuoso. No hay por qué excluir un sentido simbólico de carácter moral asociado a las «flores» y a los «cardos» que el poema menciona, pero aun así el tono del poema resulta poco convencional.

De forma similar puede considerarse la «Himnodia de las espigas», que también calca su estructura de un canto litúrgico. El poema renueva la alabanza a Dios por parte de las criaturas, tópico arraigado en la tradición religiosa, que aparece en los salmos bíblicos y que ha sido incesantemente re- 
formulado por la literatura espiritual. Un antecedente digno de consideración en el contexto cultural de este poema es el de San Francisco de Asís, y particularmente su famoso «Cántico del Hermano Sol», alabanza a Dios y a su presencia en todas las criaturas. El amor franciscano por la naturaleza - sugerido también en el poema anterior - se concreta ahora en las espigas, invitadas en esta ocasión a cantar alabanzas a su Creador. Son ineludibles en este poema las connotaciones que asocian la imagen de la espiga - ya de por sí elocuente símbolo de la fertilidad - con ideas de vida, fecundación y maternidad: «Alabadle en la plenitud de los estíos, / cuando la fuerza del sol os madura los hijos» (Torre, 1950: 42). El poema sigue desarrollando esa imagen de forma que la espiga se asocia repetidamente a una idea maternal. Nada de esto se aparta de la literatura espiritual, que enseña a alabar a Dios en todo momento y circunstancia. La nota discordante que se observa es de matiz y se relaciona con el momento en que la espiga debe alabar a Dios en el momento de su destrucción: « ...alabadle, espigas secas, / mientras vuestra carne se quiebra, / alabadle en la degollina de la siega, / en el interminable entierro de las carretas, / y en el pagano circo de las eras, / y en la tortura redonda de la piedra / y en el blanco holocausto de la muela...» (Torre, 1950: 43). La escena de las espigas evoca el martirio de los primeros cristianos, y guarda relación con la literatura espiritual, incluso con el «Cántico del Hermano Sol», donde Francisco de Asís manifiesta su desprecio por la muerte corporal, tema, por cierto, muy arraigado en la literatura mística. El poema de Alfonsa de la Torre, sin embargo, no se aplica al martirio de seres humanos, sino a un proceso común en la elaboración de la harina, lo que crea un desajuste entre la banalidad del tema y el tono heroico del que surge la ironía. En este sentido hay que considerar, igualmente, la retórica insistencia en los pormenores del tormento, a la que cabría atribuir una intención paródica.

Así como las espigas de la «Himnodia» aparecen como imágenes maternales, las rosas de «Felicitas beatorum» se asocian a la vida contemplativa. El simbolismo de la rosa y su carácter místico así lo sugiere. Ya en su Oda a la reina del Irán se podían leer los siguientes versos: «¿Tendrá la mística flor que buscaban / en la Tebaida los anacoretas?». Se trata de una referencia a los ermitaños que, a imitación del primer anacoreta de la historia, conocido como San Pablo el Ermitaño, se retiraron al desierto a meditar. La flor genérica de la Tebaida se concreta ahora en la rosa, flor que posee en la tradición cristiana un extenso simbolismo espiritual, como representación de la sangre de Cristo o de la Virgen María en su advocación de rosa mística, y que en el poema de Alfonsa de la Torre se asocia con un camino de perfección espiritual. Las espigas y las rosas tendrían, a la vez, un simbolismo opuesto en el poemario como representaciones respectivas de la vida activa 
y la vida contemplativa. También en este caso hay que apuntar el carácter sutilmente paródico del poema respecto al sermón de San Francisco, insinuándose una advertencia a las flores contra la tentación de la vanidad, que cierra una parte del poemario.

Varios poemas están dedicados a santos propios de la tradición italiana. En esta línea pueden citarse la «Antífona de Santa Cecilia», «San Bernardino», «Cantata mística» - dedicado a Santa Catalina de Siena - y, por supuesto, el «Sermón de San Francisco a las flores». Cada uno de ellos contiene claras referencias a sus vidas y, a veces, la representación verbal de algún elemento que recuerda el conjunto escultórico del Oratorio. Así, Santa Cecilia es denominada como «paloma de piedra blanca», en tanto que San Bernardino se describe como «pájaro aprisionado en una almendra», imágenes que tienen un claro referente en la obra del Duccio.

Es en la parte tercera del libro donde surge una compleja representación de varias figuras femeninas caracterizadas por ilustrar una feminidad al margen del orden social establecido

Muy importante en esta línea es el poema titulado «Juicio de Lilith». Lilith sería considerada, en diversas leyendas hebraicas, como la primera mujer de Adán, una mujer que habría querido igualarse al hombre y que, por su rebeldía, habría incurrido en el desagrado de Adán y en el castigo de Yahvé. Lilith aparece en la Biblia en una sola ocasión ${ }^{1}$, en un contexto que habla de la furia divina que exterminará o desterrará de sus dominios a quienes le hayan ofendido. Lilith, efectivamente, ha incurrido en las iras de Yahvé, aunque la única referencia bíblica hacia ella no permita calibrar el motivo o el alcance de esa ofensa. El poema se ordena, precisamente, en torno a la voz de Yahvé, es decir, en torno a un discurso sagrado que se manifiesta, acusador, contra esa criatura desviada. El juicio de Dios sobre Lilith es durísimo y se extiende a lo largo de todo el poema con carácter condenatorio, sin que se expliciten ni el motivo de la transgresión ni el posible descargo de la mujer.

Si bien la Biblia no es explícita en este aspecto, la tradición posterior la ha relacionado con los pecados de haber nombrado a Dios y de no haber querido someterse al hombre. Así, pues, por un lado, la mujer habría usurpado el derecho a la palabra, que le era vedado, mientras que, por otro, su deseo de paridad con el varón, su insumisión de mujer libre, la habría caracterizado como soberbia y rebelde. Su pretensión de no renunciar al goce sexual, negándose a ser un mero instrumento para la reproducción de la especie, la per-

1 También allí Lilit descansará / y hallará su lugar de reposo . / Allí hará su nido la serpiente y pondrá , / incubará y sacará sus huevos; / allí se reunirán también los buitres / y se encontrarán unos con otros (Isaías, 34, 14-15). 
filan como una mujer sensual y peligrosa para el orden establecido. En este sentido, Lilith vendría a representar una criatura oscura, maligna, asociada al ámbito nocturno, percepción que está en consonancia con la imaginería del libro. Definida como luna de iris congelado y como ojo enlodado, Lilith se asocia a los poderes de la noche y al conocimiento de lo oculto. Las dos imágenes citadas son referencias a un ojo - símbolo del conocimiento- que por ser enlodado o por tener un iris congelado se relacionarían con el ocultismo. Cabe, incluso, apuntar, sabiendo el interés de la autora por la astrología, que la luna fría y el ojo oscuro hacen referencia a la representación astrológica de Lilith como una luna negra. El poema se construye sobre un entramado simbólico y referencial de gran riqueza connotativa, que refuerza, mediante alusiones cultas, la censura patriarcal sobre la mujer caída. Una técnica acumulativa estructura el texto sobre la base de un juicio moral que insiste en los campos semánticos de la seducción y la esterilidad.

El reproche de la infecundidad, asociado al deseo de la mujer de disfrutar su sexualidad al margen de la función reproductora, integra destacadamente el discurso de Yahvé: «Formé para ti la rosa, / te di el espino nevado. / ¿Qué palma me has fecundado? / Te puse toca de perlas, / te ceñí el velo sagrado. / ¿Qué fruto me has madurado?» (Torre, 1950: 67-68). La parábola de los talentos se abre como inevitable asociación con la voz rotunda del amo que juzga la capacidad de su sierva para desarrollar los dones que se le han otorgado. El juicio inapelable de Yahvé está a punto de emitir su veredicto final.

El poema abunda en recursos iterativos y acumulativos. Por tres veces, al inicio del poema, se repite la pregunta de Dios: «¿Para quién te has afanado?» (Torre, 1950: 65). La voz de Dios, la máxima autoridad, acorrala a la mujer caída, exigiéndole una explicación. Por este motivo el discurso adopta muchas veces una modalidad interrogativa. Las palabras de Yahvé insisten en que la mujer ha adoptado disfraces y caretas, desarrollando de distintos modos el campo semántico de la ocultación, lo que colisiona con la ubicuidad y omnisciencia divina, ante las que son inútiles esas estrategias. El reproche de Dios en el poema de Alfonsa de la Torre evoca el relato bíblico del fratricidio de Caín, quien también debe responder de sus actos y cuyo castigo es, como para Lilith, el exilio y la errancia por la tierra.

El poema se construye sobre un hipotexto bíblico. Tal como la Biblia lo describe $^{2}$, el hábitat de Lilith es un lugar inmundo e infértil. Por su parte, el poema de Alfonsa de la Torre recrea un espacio húmedo y pantanoso, tam-

2 Y sus torrentes se convertirán en pez, / y su polvo en azufre, / y será su tierra como pez que arde día y noche; / nunca se extinguirá, / subirá su humo perpetuamente. / Será asolada de generación en generación, / y nadie pasará más por ella. / Se adueñarán de ella el pelícano y el mochuelo, / la habitarán la 
bién inhóspito. Ambos textos se refieren a un bestiario formado tanto por animales comunes como mitológicos, caracterizados por rasgos como la agresividad, el instinto depredador, la simulación, etc. Hay, incluso, coincidencias muy concretas, como las menciones a la lechuza y al chacal, o la similitud de las referencias al buitre - en la Biblia - y al cuervo - en el poema-. El texto de Alfonsa de la Torre incluye un variopinto bestiario cuyas connotaciones negativas se asimilan a la figura de Lilith. En conjunto, simbolizan una personalidad peligrosa, desviada de la norma, que actúa con nocturnidad y engaño, que se alimenta de la destrucción y la provoca. Pero donde la inventiva de la autora se desborda es en la mención de seres mitológicos, tan sólo representados en el texto bíblico por los sátiros. Los seres mitológicos amplifican y reiteran en el poema las características asociadas a la personalidad de Lilith. Por ejemplo, cuando la voz de Dios califica a la mujer como «sirena en sepulcro alzado», está reforzando las connotaciones necrófilas del personaje, que también se asocian a los animales carroñeros. La figura mitológica de la sirena, por su parte, evoca a la serpiente, puesto que en la antigüedad clásica solía representarse como un híbrido de mujer y serpiente. Desde luego, también las serpientes y sus crías habitan el espacio bíblico en el que se sitúa a Lilith, pero no conviene olvidar, dado el modo en que se ha caracterizado al personaje, el simbolismo fálico de la serpiente y el hecho de que éste sea el animal que tentó a Eva en el Paraíso. En última instancia, el pecado de Eva y de Lilith habría tenido un común componente carnal, lo que vendría reforzado en el poema de Alfonsa de la Torre por otras alusiones al carácter sensual del personaje.

A la misma clase de referencias mixtas hay que sumar el calificativo de «lechuza hiperbórea». La lechuza, como ya se ha dicho, es uno de esos animales que conviven con Lilith tanto en la Biblia como en el poema de Alfonsa de la Torre. Recuérdese, no obstante, que en la mitología griega la lechuza es el ave de Atenea, símbolo por ello de la sabiduría. A su vez, las tribus hiperbóreas eran consideradas en esa misma mitología como pueblos habitantes de regiones ignotas, supuestamente entregados a toda clase de excesos. La imagen es, una vez más, acumulativa: el afán de conocimiento y de placeres motiva la censura que recae sobre la mujer.

lechuza y el cuervo / y echará Yavé sobre ella / las cuerdas de la confusión y la plomada de la desolación; / y habitarán en ella los sátiros, / y todos sus nobles dejarán de existir. / Allí ya no habrá reino, / y desaparecerán todos sus príncipes. / Y en sus palacios crecerán las zarzas , / en sus fortalezas las ortigas y los cardos, / y serán morada de chacales y refugio de avestruces. / Perros y gatos salvajes se reunirán allí, / y se juntarán allí los sátiros. / También allí Lilit descansará / y hallará su lugar de reposo. / Allí hará su nido la serpiente y pondrá / incubará y sacará sus huevos; / alli se reunirán también los buitres / y se encontrarán unos con otros (Isaías 34, 9-15). 
Tras estas acusaciones, Dios anuncia la destrucción de Lilith y, con ella, la caída de «Leonas de Babilonia y shirrush de mirar vidriado». Esta vez, las imágenes proceden del mundo artístico, en consonancia con el motivo escultórico que da pie a todo el poemario. En este sentido, podemos recordar que algunas civilizaciones antiguas, particularmente la egipcia, nos han legado representaciones mitológicas de figuras con cabeza de leona y cuerpo de mujer. Los sensuales movimientos de la leona y su ferocidad se asocian con el arquetipo de la mujer de perdición. El shirrush, por su parte, hace referencia a la iconografía artística mesopotámica. Esa especie de dragón mitológico tiene su representación más conocida en la famosa puerta babilonia de Ishtar, diosa que posee connotaciones sexuales muy precisas referidas al amor extraconyugal.

Todos estos rasgos hacen que, desde el punto de vista de la moral tradicional, Lilith sea una perfecta representación de la pecadora, motivo por el cual Yahvé la señala como virginal espada, en referencia a la representación tradicional de la Virgen de los Dolores, que popularmente simboliza la participación de la madre en el sufrimiento del hijo. Siete son las espadas que en la iconografía tradicional atraviesan el corazón de María, número que también tiene su eco en el poema: «Siete veces te he perdido, / siete mil te he perdonado, / cinco veces me has llagado. / / Siete mares extendí / para lavar tu pecado. / Sangre lavó mi costado» (Torre, 1950: 68). En la numerología simbólica de la Biblia el siete es el número que expresa un ciclo completo; en este caso, el ciclo del pecado, el ciclo del perdón y el ciclo de la redención. Las cinco llagas y la sangre del costado son, por supuesto, las heridas de Cristo en la cruz.

La palabra de Yahvé sanciona la culpa de Lilith, por cuya causa su propio hijo ha sufrido tormento y muerte. Por ello, su sentencia de muerte se dicta como réplica a la muerte de Cristo: «Los montes se rasgarán, / el sol quedará borrado, / con tu grito prolongado» (Torre, 1950: 69). Los prodigios que el poema anuncia tienen su referente en los relatos evangélicos sobre la muerte de Jesús: en el relato de Mateo se dice, por ejemplo, que en la hora de la muerte de Jesús «las rocas se rajaron» ${ }^{3}$; en el de Marcos, Jesús gritó, antes de expirar, invocando a su Padre ${ }^{4}$; en los relatos de Mateo, Lucas y Marcos, finalmente, se dice que toda la tierra quedó en tinieblas ${ }^{5}$. El paralelismo entre los fenómenos descritos en los evangelios y la muerte anunciada para Lilith rememora la antigua ley del Talión: ojo por ojo y diente por diente.

\footnotetext{
3 Mt. 27, 51 .

4 Mc. 15,37 .

5 Mt. 27,45; Mc. 15,33; Lc. 23-45.
} 
En síntesis, el poema sobre Lilith pone de manifiesto la censura patriarcal sobre la mujer que no se somete, a la que se responsabiliza por los males del mundo y a la que se hace acreedora del máximo castigo.

En el conjunto de figuras femeninas recogidas en el imaginario poético de la autora que destacan por su condición subversiva respecto al orden patriarcal, hay que considerar también a las que Alfonsa de la Torre llama «amazonas». En la mitología clásica existen numerosas leyendas relacionadas con las amazonas, unas mujeres guerreras que, para facilitar el manejo del arco, se mutilaban uno de los pechos. Constituían una comunidad de mujeres solas, que no contraían matrimonio y que se colocaban bajo la protección de Artemisa, diosa virgen y adiestrada en el manejo de las armas. Todas estas características hablan de una tipología femenina que no se adapta a la organización social establecida: la amazona ejerce sus funciones fuera del espacio doméstico, no depende de ningún varón, mantiene relaciones sexuales libres, etc. Este plano legendario tiene un preciso reflejo a lo largo del poema: las mujeres pasan «solas, sin cinturas y sin pecho», e igualmente ostentando los «recamados cinturones» que eran atributo de esas míticas mujeres. Como «nevadas de palomas virginales» las define también la autora, haciendo uso del antiguo concepto de virginidad que no se refería a la estricta castidad, sino a la soltería. De hecho, el matrimonio, que las amazonas legendarias rechazaban, aparece en el poema de Alfonsa de la Torre como una amenaza, cuando las describe «acosadas por montes nupciales».

En el plano mitológico, las amazonas configuran una identidad femenina alternativa por tratarse de mujeres independientes, que anteponen la defensa de su territorio al matrimonio y a la procreación. La amazona, por otra parte, encarna una imagen de carácter andrógino compatible con el concepto de homosexualidad lésbica. Desde esta perspectiva, aunque de forma algo menos explícita, ha sido ya explicado este poema (Ramírez de Arellano, 1961: 5384). El importante análisis al que me refiero destaca pormenorizadamente el carácter disémico de numerosas imágenes utilizadas en el poema por Alfonsa de la Torre, refiriendo esa característica a la dualidad de la figura femenina en torno a la que el texto se estructura y también al carácter «bicéfalo»esto es, a la capacidad de disimulo - de que un sector de estas mujeres se dotan para eludir la presión social. Ramírez de Arellano relaciona el adjetivo «veladas» con que se caracteriza a las amazonas precisamente con la autocensura utilizada como escudo ante la marginación social que su condición acarrea. En este contexto, el carácter guerrero de las amazonas se asocia perfectamente con la necesidad de reducir a la jauría de «lebreles jadeantes» que las persiguen. La autodefensa se orienta, bien por la vía de la agresividad «Pasan / lanzadas, / pasan afiladas, / semejantes / a agudas / espadas, / a dar- 
dos / penetrantes, / a tizonas enarboladas...»- o bien por la vía del disimulo: «pasan ateridas / y suaves, / escondidas...». La mujer con una orientación sexual lésbica viola de muchas formas el papel preestablecido para ella en la sociedad patriarcal, manteniéndose independiente del varón y practicando una sexualidad al margen de la procreación. La censura social y moral contra las lesbianas es tan severa que incluso en sociedades más tolerantes que la española de 1950 - fecha en que este libro fue publicado-, muchas de ellas temen reconocer públicamente su condición sexual. Alfonsa de la Torre aborda por lo tanto un tema verdaderamente tabú para la sociedad en la que vive y lo hace para defender la vivencia coherente de la propia orientación sexual. La autora califica como amazonas «veladas» a aquellas que niegan su verdadera naturaleza para integrarse en la sociedad, a las que - como el prólogo del libro indica - traicionaron al amor incurriendo en la farsa de un matrimonio indeseado o en otras formas de hipocresía.

Como ya se vio anteriormente, el juicio de Yahvé es implacable con la mujer caída, pero en el siguiente poema, «Pesadilla de las infanticidas», no hay juicio más severo ni castigo más terrible que el de la propia conciencia. «Buscan a sus hijos»: este verso se repite dieciocho veces en el poema, dos veces en cada estrofa, siempre en el primer y cuarto verso. Todos los versos, por otra parte, empiezan con el presente del verbo buscar. El poema tiene, por lo tanto, una estructura repetitiva que pretende trasladar al lector la obsesión de esas mujeres a quienes la culpa no dejará jamás de atormentar y perseguir. Por eso buscan incesantemente a sus hijos por todos los rincones de la realidad y por todos los resquicios de su mente. El infanticidio no es un tema infrecuente en la literatura popular y en la tradición oral. El «coco», el «hombre del saco», «el sacamantecas» y otros similares son figuras que tienen su equivalente en todas las culturas y que se usan para asustar a los niños. El caso específico del infanticidio cometido por una mujer y, más concretamente, por la madre del niño en cuestión, tiene también precedentes. En España, el tema había sido previamente tratado en la literatura de autoría femenina, al menos en un caso. Caterina Albert, más conocida por el pseudónimo de Víctor Català, escritora vinculada al naturalismo catalán, trata el tema centrándolo en la tragedia de una mujer conducida a la locura por la presión social - y, específicamente, patriarcal -, sobre un embarazo no deseado (Català, 1967). En la mitología clásica, así como en las tradiciones y leyendas americanas y orientales, existen dioses, héroes y personajes infanticidas, lo que muestra hasta que punto el tema ha impregnado el imaginario colectivo. Pero los antecedentes del poema de Alfonsa de la Torre, probablemente, no se encuentran entre los ejemplos anteriores. Es más razonable suponer que su inspiración provenga de la fama adquirida por algunas de 
esas mujeres que están vinculadas a su propio imaginario poético, como las amazonas y la propia Lilith. Respecto a las amazonas, la leyenda recoge su costumbre de conservar con ellas solamente a su descendencia femenina, por lo que se decía que daban muerte a los hijos varones. Respecto a Lilith, una variante de las leyendas asociadas a su figura dice que, en venganza por la muerte de sus hijos - castigo que le había impuesto, por su desobediencia, Yahvé-, habría jurado asesinar a todos los recién nacidos que alcanzase de la descendencia de Adán. «Pesadilla de las infanticidas» puede tener presentes, tal vez, a estos personajes, pero, de modo general, puede recalcarse que aborda el tema de la maternidad desde uno de sus ángulos más espinosos. En contraposición a la retórica exaltadora del «ángel del hogar» que caracterizaría, en la época, el tema de la maternidad, Alfonsa de la Torre aborda la variante más cruel del tema. Uno de los versos del poema dice: «buscan a sus hijos por las esquinas de Roma». El motivo de una localización geográfica tan concreta - en un contexto de búsqueda más bien difuso, referido en el poema a las pesadillas que afloran del subconsciente de las infanticidas y al sentimiento de culpa que las obsesiona - se explica por el entorno italiano que da pretexto a las reflexiones de la autora. Otra explicación posible es la extendida costumbre, en la Roma clásica, de abandonar o dar muerte a los niños deficientes o cuya manutención era inviable. Todo ello puede explicar - naturalmente, en torno al motivo artístico del oratorio - la atención que la autora presta al tema. Lo que hay que destacar, no obstante, de forma independiente, es que ella haya elegido abordar, en este poema y en los anteriores, formas de feminidad que chocan frontalmente con lo establecido, mostrando facetas diversas de la compleja psicología humana.

Cerrando el ciclo de las figuras femeninas del libro, se encuentra un poema titulado «Il pianto de la Madonna» (Torre, 1950: 87-88). Fuera del título, no hay en todo el poema una sola mención de la Virgen y, menos, una descripción de su imagen. Lo que el poema desarrolla es la descripción de extraños fenómenos, señales de un acontecimiento extraordinario. Aunque el poema no lo explicita, en el prólogo al libro se dice que «la Madonna llorará lágrimas de nieve sobre la pureza de las bellas almas perdidas» (Torre, 1950: 9) y, en efecto, la profusión de señales que acompañan ese llanto parece anunciar el fin del mundo. La visión apocalíptica participa de un imaginario donde el agua - extensión metafórica de las lágrimas marianas - cobra protagonismo sin que, pese a su simbolismo purificador, acaben de lavar la culpa del mundo. La hora en que la Madonna llora «el duelo del gozo» todos los sentidos participan, en el poema, de impresiones desagradables como frío, amargor, dureza, etc. El texto, por lo demás, está compuesto sobre una base repetitiva: rimas en eco, paronomasias, anáforas, concatenaciones, etc., 
componen una atmósfera poética donde la sonoridad y el ritmo acompañan un tono de salmodia que acrecienta el vértigo de las imágenes visionarias y los juegos de opuestos que describen un momento sobrenatural. «Las uvas brotan lágrimas», dice el poema, describiendo metafóricamente la consistencia acuosa de unos ojos arrasados por el llanto. La Madonna de Alfonsa de la Torre, por otra parte, tampoco es una imagen convencional puesto que no aparece en ninguna de sus advocaciones comunes, ni en sus gestos o representaciones más habituales: es un poder, una energía que brota del sufrimiento, cuya fuerza es capaz de transformar la materia. Sus lágrimas denuncian la muerte de un inocente por redimir al mundo y anuncian el fin de los días.

Con este poema, Alfonsa de la Torre pone fin a su viaje íntimo. El peregrinaje y la reflexión han dado como fruto un descenso de la mujer al centro de sí misma. Los dos poemas siguientes cierran el poemario desvelando dos conclusiones básicas. Por una parte, la condición interina del ser humano se asimila a las figuras del turista y del viajero. Alfonsa de la Torre censura al primero por su actitud superficial, en tanto que el viajero encarna una búsqueda del conocimiento que la autora promueve como actitud ante la vida. Por otra parte, la autora reflexiona sobre el desgaste que el tiempo y la costumbre ejercen sobre cada elemento de la realidad y desea la llegada del día en que cada cosa se elevará sobre su contingencia y alcanzará su meta definitiva en la presencia de Dios, es decir, el momento en que cada cosa desvelará su naturaleza profunda, por encima de las apariencias. El conocimiento de sí mima y el deseo de aceptación e integración son el sustrato de las reflexiones de la autora. La famosa portada del Oratorio de San Bernardino que ha sido pretexto del viaje resulta, a la postre, actuar como un mandala sobre el que la mujer medita, tratando de avanzar en su conocimiento interior como camino para el equilibrio psicológico.

La poesía de Alfonsa de la Torre, una de las más logradas y originales de su tiempo, se presenta en la actualidad como un desafío para el lector. Las distintas capas de sentido que se superponen en los poemas, su arquitectura simbólica, su elaborado imaginario, la muestran como una autora rica en matices, de orientación culturalista y, también, como una mujer adelantada a su tiempo. Oratorio de San Bernardino es un libro que contiene una invitación a la búsqueda del conocimiento y a la espiritualidad, pero también, tanto en la construcción de las figuras femeninas como en el distanciamiento irónico de algunos textos, resalta el conflicto de la autora en relación al poder patriarcal.

El tono elevado del poemario contribuye, desde luego, a difuminar al sujeto poético que, no obstante, se deja entrever en aspectos concretos $y$, sobre 
todo, en un poema titulado «Canción de la muchacha que caminaba a través del viento» (Torre, 1950: 71-78), donde la figura central del poema, constituida en «alter ego» de la autora, pone de manifiesto las dificultades cotidianas que surgen cuando uno actúa a contracorriente. Éste, entre todos los poemas del libro, es el que se presenta con un carácter más íntimo y personal. Las primeras estrofas se pliegan a una descripción artística que se introduce en el poema como elemento distanciador: «Miradme, soy de barro, / mi base media esfera / dos alas me sostienen / erguidas en el aire: las puntas de mi velo». Enseguida, sin embargo, la muchacha cobra vida. En primera persona del singular, pronto se define como «más que forma grata», como muchacha de carne y hueso, nacida a la vida por el soplo de un «alfarero de espacios». La imagen, recurrente en la poesía de autoría femenina de esos años, remite a la narración del Génesis. A partir de ahí, el barro que empieza siendo en el poema el soporte material de una pieza escultórica -impresión corroborada por el sexto verso que dice: «Pudiera ser tanagra»-, pasa a simbolizar la contingencia del ser humano, su capacidad de arrostrar toda clase de dificultades y, también, su fragilidad ante la dureza de la experiencia cotidiana: «Miradme, ya me yergo, / soy de frágil arcilla, / me romperé si caigo, / me anegaré si escucho / las voces que me siguen». La muchacha que camina desafiando a las fuerzas de la naturaleza revela el esfuerzo titánico de ese empeño. Las metáforas finales, en las que la muchacha se representa a sí misma como un «lebrel» y se define acosada por «perros», encamina el poema hacia el acoso y la hostilidad que cercan su experiencia cotidiana y, de forma indirecta, revelan la alteridad de esa experiencia.

El último libro publicado por la autora, Plazuela de las obediencias, es, nuevamente, un poemario original, dividido en tres partes que van desde la reconstrucción fragmentaria de la memoria personal hasta la figuración de un futuro «presentido» o imaginado por la autora. El libro, en su conjunto, puede considerarse $-\mathrm{y}$ así consta en su dedicatoria - como un homenaje a todos aquellos que, a lo largo de los siglos, han hecho su aportación al conocimiento humano.

Entre los poemas volcados hacia la memoria personal, algunos rescatan recuerdos de la infancia, de la que ofrecen singulares retratos de personajes populares, abordados desde una poética llena de reminiscencias tradicionales. Puesto que en la poesía de Alfonsa de la Torre la mirada introspectiva siempre aparece tamizada por filtros superpuestos, vale la pena mencionar en este bloque un poema titulado «Nana para dormir a una muñeca rota» (Torre, 1969: 31-32), poema que permite vislumbrar la infancia de la autora, difícil por motivos de salud. A través de un juego ingenuo de palabras se introducen en el texto dos ideas básicas: la identificación de la voz poética con la per- 
sona de Alfonsa de la Torre y el contraste entre el libre vuelo de las aves - en este caso representadas por el engañapastor - y el encierro de la niña limitada a oler «violetas de mentirijillas». Otros poemas relacionados con la representación poética de la mujer son, por ejemplo, «Canción de la enamorada» $\mathrm{y}$ «Llanto por la cierva acosada». El primero es una poesía de corte popular donde la mujer propone un encuentro con su enamorado con un discurso lleno de insinuaciones sexuales. «Llanto por la cierva acosada» desarrolla, en cambio, un inquietante paralelismo entre una novia asesinada y una cierva herida de muerte por su cazador. La autora entona, con intenso patetismo, la elegía por la joven mujer. Aunque ceñido a modelos populares, el poema posee fuerza trágica y evoca con imágenes muy vivas el dolor de la pérdida. El tema, por otra parte, trata de la violencia ejercida sobre la mujer, representando a ésta como una presa indefensa.

La fuerza del destino, el conjuro de sus misterios, los poderes que en él intervienen, centran el segundo apartado del libro en un tono que quiere ser festivo y despreocupado. En este conjunto, «Expectación de la rosa» destaca como una advertencia respecto a la condición efímera de los seres vivos. El poema, no obstante, superpone a este tópico esencial otros niveles de sentido. Uno de ellos explora la relación entre belleza y poesía, renovando así un simbolismo frecuentemente asociado a la rosa. El aspecto sobre el que quisiera llamar la atención, sin embargo, es la asociación de la rosa con la figura de Salomé, uno de los personajes que acostumbran a representar la perversidad femenina, mito singularmente desarrollado en las artes desde la segunda mitad del siglo XIX. Salomé y la rosa comparten el simbolismo evidente de la belleza cruel, circunstancia en la que se basa el paralelismo desarrollado en el poema.

En relación al protagonismo alcanzado por la mirada, en la obra de Wilde, los varones que miran a Salomé con demasiada intensidad caen presos de su seducción y bajo su dominio. En este sentido puede interpretarse el efecto que la apertura de la rosa causa sobre el arquitecto Bramante: «Bastó que se abriera / en Roma / para que Bramante / diera / palomar a una Paloma» (Torre, 1969: 76). El simbolismo de la paloma como ave de la paz identifica el espacio arquitectónico como el claustro de Santa Maria della Pace, obra, en efecto, del arquitecto Bramante. De igual modo, el intercambio de miradas entre Dante y la rosa se imagina como origen de la Divina Comedia. La propuesta es ambivalente: de una parte, sugiere el poder creador de la belleza; de otra, entreabre el camino del amante hacia los infiernos. Esa misma ambigüedad se mantiene en otra vertiente que adopta el tema. En ella, la rosa, calificada como «Parsifálica» y «graálica», encierra una alusión al esoterismo cristiano donde la rosa representa el Grial, la copa con la sangre de Cristo. 
Muerte y vida - vida eterna, incluso - se integran ahora en esta alusión, en cuyo contexto también se alude a la leyenda de Parsifal quien, en busca del Santo Grial, sufre el encantamiento de unas doncellas-flores que seducen y destruyen a los caballeros que se internan en tan peligroso jardín. La idea de la seducción mortal de la rosa también aparece en el poema de Alfonsa de la Torre. Al ir perdiendo sus pétalos, la rosa ejecuta una singular danza de los siete velos, dejando al descubierto su tallo. La alianza de Eros y Thanatos se evoca en esa danza sagrada donde la rosa, mientras deja caer sus velos, sella su completa consunción.

La pasión por la belleza tiene también connotaciones trágicas al ser contemplada como un arma mortífera que puede volverse en contra del propio artista. Alfonsa de la Torre transpone de este modo su propia ansiedad en torno al acto creador, realizando una de las más inquietantes poéticas del momento surgidas de una pluma de mujer.

Cabe mencionar, asimismo, la existencia de dos poemas que, en tono menor, afirman la capacidad de la mujer para transformar el mundo y para modificar la situación del propio colectivo. En uno de ellos aparece la figura de la que llama «la estrellera» (Torre, 1969: 71), mujer legendaria que habría hecho acopio de grandes conocimientos astronómicos, hasta el punto de poder comunicarse con seres extraterrestres. En otro, titulado «Cinemática evolucionista» (Torre, 1969: y ss.), traza, humorísticamente, una especie de trayectoria del género femenino para desembocar en el deseo de que pueda llegar a transformarse el concepto tradicional de mujer: «que poco a poco / y para siempre / van dejando de ser grávidas, / que poco a poco y para siempre / van dejando de ser eso / que hasta ahora se ha llamado mujeres / para empezar a ser otra cosa, / para pertenecer a otra / muy distinta fauna». El rechazo del rol tradicional de la mujer — «van dejando de ser grávidas» - confirma la propuesta, por parte de la autora, de una feminidad más volcada hacia el saber. El poema «María Humanide», escrito también en tono menor, encierra un profundo deseo de transformación en lo relativo a la condición femenina. Tomando el nombre de María Humanide como la unión del genérico femenino al concepto de humanidad total, la autora reformula un trabalenguas popular, representando en el personaje de su poema a un sector de las mujeres que participan conscientemente en la construcción del conocimiento, abriéndose a sí mismas las puertas del saber y facilitando su integración igualitaria en una humanidad renovada.

En este punto es donde merecen una mención aparte las figuras femeninas que guardan relación con los poderes ocultos, como la que aparece en «Cancioncilla de la maestra herbera». Aunque referida con un apelativo inocente e incluso prestigioso, el monólogo de la «maestra herbera» va enumerando 
las diversas artes de su oficio asociando a éste un poder efectivo sobre sentimientos y conciencias. En su discurso, la «herbera» va progresivamente adoptando la personalidad de la «bruja» en un crescendo que culmina proclamando su alianza con el diablo. La mujer deja así de ser una eficaz cooperadora en cuestiones sentimentales para convertirse en un modelo de perversidad. Esa transformación viene apoyada en el texto por un cambio de tiempo verbal que pasa del «yo soy» - «la pastora», «la zagala», «la doncella»- al «yo seré» - «una lamia», «la sanguina»-, variando sensiblemente el campo semántico de los atributos. La estrofa final regresa al tiempo presente - «yo soy la hechicera» - instalándose, retadora, en la personalidad perversa. Estas variaciones en torno a la identidad del sujeto poético pueden interpretarse como la doble percepción - íntima y social - de un personaje que, si acaba identificándose con su lado más oscuro, es únicamente para desafiar a la sociedad que la margina. La «herbera», «bruja»o «hechicera» es una figura transgresora: «A menudo la transgresión cometida por la mujer consiste en su inadecuación al papel que el patriarcado le asigna y a su apropiación de comportamientos considerados propios del varón» (Bastida, 1999: 97). En este caso, el conocimiento de remedios naturales le otorga un poder y un ascendiente sobre su comunidad que son vistos con recelo por el poder patriarcal. Para Alfonsa de la Torre, sin embargo, se trata de un personaje atractivo por muchas razones. Por un lado, conecta con el interés de la autora por temas relacionados con la magia. Por otro lado, se refiere a un tema importante en la lucha feminista como es el acceso al conocimiento por parte de la mujer. La sabiduría de la «bruja» popular, al margen de creencias supersticiosas, le permite el control de sustancias con diversas propiedades, bien sea alucinógenas o curativas, lo que le otorga plena autonomía e, incluso, un poder sospechoso de alianza demoníaca a los ojos de la Iglesia. El personaje de la «herbera» conecta, en la poesía de Alfonsa de la Torre, con las magas, brujas y alquimistas que aparecerán en su «Letanía y ronda de las sorores místicas ante el horno alquímico», poema que constituye un verdadero homenaje hacia las mujeres que, desafiando las leyes patriarcales, han cooperado, desde posiciones marginales, en la construcción del conocimiento humano.

El poema enumera, como una letanía, al menos dos docenas de nombres femeninos de resonancias literarias, históricas o mitológicas. Pronto se descubre que todas ellas, de un modo o de otro, guardan relación con la magia o la alquimia. Esto último es lo que anuncia el marbete de «sorores místicas» con que se las califica. La soror mística sería la ayudante, discípula o colega del alquimista, una mujer que cumple una función vital en el proceso alquímico para cuya perfecta realización necesitan complementarse el principio 
masculino y el principio femenino. Alfonsa de la Torre nombra y rinde homenaje a estas mujeres en el poema. Algunos de los nombres que menciona pertenecen, como ya se ha dicho, a colaboradoras de magos o alquimistas célebres. Así, Viviana y Merlina son referencias a la aprendiz de Merlín; Pafnucia es el nombre de la esposa del célebre alquimista Nicolás Flammel, de quien se supone que halló la piedra filosofal y el secreto de la inmortalidad; Theosobeia, por su parte, fue, según la tradición, discípula del alquimista Zósimo. En un plano literario, el nombre de Fausta hace referencia al Fausto de Goethe, que vende su alma al diablo a cambio de la eterna juventud, cuyo elixir fue una de las quimeras de la alquimia ${ }^{6}$. También el nombre de Serafita evoca reminiscencias literarias como posible referencia al personaje de Balzac, que da nombre a una de sus novelas. A su vez, la ambigüedad sexual del personaje tendría correspondencia con el concepto de androginia manejado por la alquimia esotérica. A estas reminiscencias hay que añadir las del ciclo artúrico: Viviana, antes mencionada, y Melusina. Melusina es un personaje sobrenatural, que acepta transformarse en mujer por amor y que acaba convertida en lamia por una promesa incumplida. Se trata de un personaje inquietante, al que se suponía relacionado con poderes mágicos: «[...] el hombre medieval debía ver en la figura de Melusina algo inasible, de un poder enorme y misterioso, pues no en vano era la fusión de tres seres malditos por la Iglesia: la mujer, la serpiente y el hada» (Alvar, 1983: XI). En este sentido, Melusina se asocia en el imaginario colectivo a figuras mitológicas como Pandora y Casandra, mujeres de uno u otro modo enfrentadas al poder patriarcal.

Mujeres relacionadas con la alquimia o la magia son también Pafnucia, Cleopatra - una de las más citadas en los tratados antiguos - que, de referirse a la reina de Egipto, recordaría la fama de maga que le granjearon sus conocimientos de astronomía y, en otra dimensión completamente distinta, Samantha, que es una probable alusión a Samantha Stevens, personaje principal de la serie «Embrujada», emitida por primera vez por Televisión Española en 1965, fecha muy cercana a la publicación de Plazuela de las obediencias.

La letanía desgrana también nombres que evocan alguna forma de transformación, sobre todo espiritual. Recuérdese que la transmutación o transformación de los metales era uno de los ejercicios de la alquimia práctica, encaminada a la conversión de metales corrientes en oro. En la alquimia

${ }^{6}$ Goethe leyó apasionadamente los escritos alquímicos, que aplicó a sus investigaciones sobre Historia Natural. Paralelamente se dedicó al estudio de las ciencias naturales, la mística y la cábala, estudios que trató de ocultar y sólo reveló a los más íntimos (Priesner-Figala: 235). 
esotérica, la transformación espiritual y el conocimiento verdadero del propio ser se consideraría también una meta de los iniciados. En relación a esta vertiente espiritual de la alquimia puede citarse el nombre de Euthicia, madre de Santa Lucía, quien sufre una transformación íntima que la lleva a abrazar la pobreza.

No cabe negar, por otra parte, el gran interés por la alquimia que tuvo Karl G. Jung. En este sentido, la enumeración «Jawwa-Eva / [...] / Helena, / María, / Sophia» puede considerarse una alusión a su Piscología de la transferencia, tratado en el que refiere una progresión del anima -concepto asociado al Eros - representando, cada uno de esos nombres, una etapa diferente de la evolución. Más adelante, el poema menciona a la Sulamita, la célebre amada del Cantar de los Cantares, a la que se asocia la última fase de la mencionada progresión. Esa fase, que lleva el nombre de «Sophia», se relaciona con el conocimiento y con la espiritualización del eros, que para Jung no se identificaba estrictamente con la libido. Todo ello guarda relación con el desarrollo del conocimiento y con la búsqueda del significado profundo de las relaciones humanas y de la propia vida, lo que también remite a una transformación espiritual y a una contribución al progreso del saber humano.

Cabría, asimismo, distinguir otro grupo en el listado de «sorores místicas». Este grupo estaría constituido por nombres que identifican principios femeninos universales, como Selene, la diosa lunar, representación de una feminidad vinculada a poderes oscuros, principio al que serían también afines Melusina, Pandora, Casandra, Lilith, etc.

El poema acumula toda clase de alusiones a la alquimia, dando lugar a una superposición de significados difícil de sintetizar: el nombre de Aurora, por ejemplo, posible referencia a la Aurora consurgens, obra de proyección alquímica atribuida a Santo Tomás de Aquino; el atanor, hornillo empleado en las transmutaciones practicadas por el alquimista; la piedra, referencia a una quimera principal de la alquimia, que fue el hallazgo de la piedra filosofal; el aleph, principio alquímico de todas las cosas; el pelícano, que da nombre a un objeto del instrumental empleado por el alquimista, pero que vale también como nombre alquímico para referirse a Cristo; Afrodita, que en la misma tradición, es el nombre que recibe el elemento rojizo del cobre - color atribuido al cabello de las brujas - que, a su vez, representa el ideal andrógino, etc.

La retahíla de figuras femeninas adopta también otra orientación, reflejada en el siguiente fragmento: «Ni Isis, ni Lilith, / ni Iblis, / ni Hybris». Este conjunto de personajes evocan la soberbia ante Dios, contraria al principio de humildad requerido por la obra alquímica. A ella se oponen, irónicamente, virtudes conventuales - «constancia y leticia»- y la máxima de la orden be- 
nedictina: «ora et labora». El afán pagano de las «sorores místicas» se solapa a las consignas de las órdenes religiosas católicas en tanto que unas y otras desarrollan trabajos del espíritu, aunque nunca deja de apreciarse un leve toque irónico en el tratamiento de todo lo relacionado con la liturgia católica.

Sin extenderme más en estas prolijas explicaciones sobre los elementos de la «letanía», bueno será recordar que el poema se califica, por parte de la autora, como «letanía y ronda». El último concepto evoca la circularidad, el eterno retorno, el renuevo cíclico. En este sentido hay que destacar la estructura circular del propio poema que comienza con la letanía de «sorores místicas», se desvía hacia la concreta figura de María Sabina — de la que se hablará más adelante - y termina iniciando, otra vez, la misma letanía. Elementos de circularidad son también en el poema el corro en torno al fuego - tan evocador de las prácticas de brujería-, la ronda de los cisnes de Apolo, la rueca - instrumento para hilar que trabaja mediante una rueda y que la mitología clásica asocia con personajes femeninos que controlan el destino humano- $y$, por encima de todo, la rueda imaginaria que provocaría la alternancia de todas las mujeres citadas en la tarea conjunta de construir una feminidad alternativa, desvinculada de los moldes tradicionales de género y orientada a participar en la construcción del edificio del saber.

El poema de Alfonsa de la Torre es, sobre todo, un canto a la mujer en su contribución al desarrollo del conocimiento humano y, por ello mismo, constituye una recusación de la subordinación y marginalidad de la sabiduría femenina en las sociedades patriarcales. La misma consideración de las «sorores místicas» como meras ayudantes del alquimista es una percepción injusta del papel activo que desarrollaron en sus respectivas tareas, y el hecho de que Alfonsa de la Torre las nombre excluyendo del texto toda mención a los varones con los que trabajaron, es una forma de reconocer, de forma autónoma, sus aportaciones.

En un contexto de tanta riqueza connotativa, la mitad del poema está dedicado a una sola figura femenina, una mujer histórica, contemporánea, que el poema identifica como María Sabina o, también, como María la azteca. Esta mujer fue una india mazateca nacida en Huautla - México- en 1894. María Sabina - cuyos apellidos no constan en su partida de bautismo, como era frecuente en la época - se hizo muy famosa como curandera gracias a los estudios divulgados por el micólogo R. Gordon Wasson, quien conoció de primera mano el uso chamánico que la india hacía de unos hongos alucinógenos científicamente llamados psylocibes. La fama mundial que adquirió María Sabina, a consecuencia de la divulgación de los trabajos de Wasson, atrajo a muchos curiosos - hippies, estudiosos, periodistas y per- 
sonalidades célebres - al lugar donde la anciana mazateca vivía, deseosos de participar en una de sus «veladas» o rituales chamánicos. Hoy sabemos, a través del relato autobiográfico de la mujer (Estrada, 1977) que María Sabina no pudo comprender el interés que los hongos despertaban en gentes que no acudían a ella en busca de curación, y que consideró irrespetuoso y destructivo el empleo que «jóvenes de uno y otro sexo, de largas cabelleras, con vestiduras extrañas» (Estrada, 1977: 112) hacían de lo que ella conocía como «niños santos». María Sabina fue, tal vez, la última representante de una tradición ancestral que en su cultura está ligada a la religión y se practica con fines terapéuticos.

Alfonsa de la Torre tiene noticia de la existencia de esta mujer y relaciona su oficio con el de las alquimistas, profetisas, brujas, magas, pitonisas, etc., que ha ido enumerando en la primera parte del poema. El ritual chamánico de María Sabina representa una forma de conocimiento apartada de los cánones occidentales y conservada por sus gentes a lo largo de los siglos, una sabiduría diferente que la poeta asocia a otras formas antiguas de conocimiento: «Sabina lo sabe: / lo que ignoran todos, / lo que lejos late. / / Tal vez lo sabían / las que por el fuego / murieron un día. / / Tal vez lo sabían / en Delfos y Eléusis / tantas pitonisas. / / Los cisnes de Delos / también lo supieron / sin humos ni velos» (Torre, 1969: 110).

Brujas, magas, hechiceras, alquimistas o chamanesas, las mujeres que aparecen en el poema de Alfonsa de la Torre representan el acceso a formas de conocimiento no controladas por la razón, vinculadas a prácticas marginadas por la civilización occidental. Mujer, sabiduría e independencia respecto al varón forman una tríada difícil de asimilar por la sociedad establecida; por ello mismo, Alfonsa de la Torre, en cuya obra no dejan de aparecer modelos femeninos desviados del rol tradicional, les rinde homenaje en su poesía, envolviendo en una palabra rica en matices, cuajada de símbolos, cargada de resonancias culturalistas, una de las posiciones más radicales en cuanto a la defensa de la condición femenina que puede encontrarse en la poesía de postguerra.

\section{REFERENCIAS BIBLIOGRÁFICAS}

Alvar, C. (1983). «Prólogo». En Melusina o la noble historia de Lusingan, Jean d'Arras, IX-XVI. Madrid: Ed. Siruela.

BASTIDA RODRÍGUEZ, P. (1999). Santas improbables: re/visiones de mitología cristiana en autoras contemporáneas. Oviedo: KRK.

CATALÀ, V. (1967). Teatre inèdit. Tàrrega: F. Camps Calmet. 
EstradA, Á. (1977). Vida de María Sabina: la sabia de los hongos; con la traducción de cantos chamánicos mazatecos, cantados por María Sabina. México: Siglo XXI.

Guillén Acosta, C. (2001). Poesía Española 1935-2000. Madrid: N y C.

Torre, A. de la (1943). Égloga. Prólogo de Josefina Romo. Madrid: Edit. Hispánica.

- (1948). Oda a la reina del Irán. Madrid: Tall. Gama.

- (1950). Oratorio de San Bernardino. Madrid: Imp. Silverio Aguirre.

- (1969). Plazuela de las obediencias. Madrid: Imp. Aguirre.

RamíreZ de Arellano, D. (1961). Poesía contemporánea en lengua española. Madrid: Murillo. 